Arab Univ. J. Agric. Sci., Ain Shams Univ., Cairo, Egypt

28(3), 845-856, 2020

Website: http://ajs.journals.ekb.eg

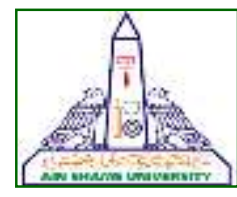

\title{
APPLICATION OF HACCP SYSTEM IN CATERING SYSTEM AND MICROBIOLOGICAL QUALITY OF ROASTED CHICKEN MEALS
}

\author{
Ali H.R. ${ }^{{ }^{*}}$, Abdel daim Y.A. ${ }^{1}$, Hammad Y.A. ${ }^{1}$ and Sedik M.Z. ${ }^{2}$ \\ 1- Food Sci. Dept., Fac. Agric., Ain Shams Univ., P.O. Box 68, Hadayek Shoubra 11241, Cairo, \\ Egypt \\ 2- Microbiology Dept., Fac. of Agric., Cairo Univ., Giza, Egypt
}

*Corresponding author: hussien elswify@hotmail.com

Received 15 August, 2020

Accepted 21 September, 2020

\section{ABSTRACT}

This study aimed to work out the microbiological quality of roasted chicken ready to eat meals $(n=240)$, swabs of labor surfaces in contact with food $(n=390)$, and the food handlers hands $(n=90)$ in catering services within the university dormitory females to assure a secure supply of food for colleges students. The results obtained appeared no contamination with $L$. monocytogenes, Salmonella spp., Shigella spp., and Clostridium perfringens before the applying of the HACCP framework. While the fluctuation within the microbial numerous total viable bacteria, total molds and yeasts, $B$. cereus, Staph. aureus, spore-formers, and coliforms in served meals ascribed to inadequate handling or processing procedures, multiplication of microorganisms during thawing and cutting of chicken, poor hygiene of utensils, and equipment as well as the survival of microorganisms to the cooking process. The examined chicken samples from receiving to serving were $1.12 \times 10^{5}, 7.4 \times 10^{3}, 2.8 \times 10^{4}$, and 1.6 $X 10^{3}$ in washing chicken, thawing, and washing steps respectively. The lowest value was $3.98 \times 10^{3}$, $3.2 \times 10^{2}, 1.2 \times 10^{3}$, and $6.1 \times 10^{2}$ in serving, dressing, washing, and receiving steps, respectively. Swabs samples analysis which taken before and after HACCP application from handlers, utensils, equipment and work surfaces observed different levels of significance in the reduction of microbial load in one or more of selected examination. Application of the HACCP framework shows a low rate of examined microorganism with a decreasing percentage reached $100 \%$ of 1 or more microbial groups in the statistically serving step $(p<0.05)$ which demonstrates a critical impact of HACCP application. HACCP framework can be moreover utilize to control the safety and quality of prepared ready to eat meals, based on microbiological specifications to improve the microbiological and healthy quality of foods to reduces the reliance on the end product inspection that ultimately resulted in improving food safety, reducing costs associated with food hazards.

Keywords: Microbiological food quality; HACCP; catering; roasted chicken meals.

\section{INTRODUCTION}

Globally, food safety problems in the most foodserving establishments arise from bad holding (44\%), inadequate cooking or reheating $(9 \%)$, unsafe sources $(18 \%)$, cross-contamination from infected persons and contaminated equipment (27\%) in addition to toxic chemicals (2\%) as reported by (WHO, 1999).

To ensure the safety of foods prepared by catering systems the microbiological contamination that depends on the quality of the raw materials and the application of good manufacturing practices (GMPs) by the staff must be assessed. Total mesophilic aerobes, spoilage and pathogens such as: Salmonella spp., Listeria monocytogenes, Escherichia coli, and Staphylococcus aureus are main contaminants of food supplied by a catering service. So that foods can be considered as a source of many foodborne outbreaks (Osimani et al 2016a). Salmonellae, $S$. aureus, E. coli, and $\mathrm{Cl}$. perfringens are important bacteria causing food poisoning leading to gastroenteritis and other health complications (CDC, 2015). 
Mass catering is classified as commercial, noncommercial segment which includes colleges and university establishment, schools business and industry and public food services. Conditions that allow the proliferation and transmission of diseasecausing organisms such as bacteria, viruses and other food-borne pathogens is result of Unsanitary practices during food preparation, handling and storage (Akabanda et al 2017).

Cross-contamination is the main reason of existence of pathogens in foods due to many factors mainly unsatisfactory cleanliness surrounding environment and staff, in addition to inadequate conditions such as temperature abuse or inadequate cooking. These factors facilitate microbial growth or survival. Contamination ensues at any point from food chain either during food preparation or during serving. A wide range of illnesses are involved under foodborne diseases which caused by ingesting foods contaminated with microorganisms. A significant number of foodborne diseases cases are lethal, although most of the cases are trivial, thus a lot of money is lost as a result of recurrent recalls and medical expenses (Davis, 2018).

Therefore the aim of this study was to determine the microbiological quality, apply HACCP system through the catering services within the university dormitory females to assure a secure supply of food for college's students and roasted chicken ready to eat.

\section{MATERIALS AND METHODS}

\section{Sampling plan}

A complete of 720 samples of natural random chicken and swab samples throughout the food production chain were studied from 2017 to 2019 (Table 1).

\section{Sample collection}

A total of 240 samples of chicken were collected from the university dormitory meals including different stages of preparation till serving (raw, defrosted, marinated, and cooked) of roasted chicken. It kept in separate sterile plastic bags and transferred on to the laboratory in an icebox under the entire aseptic condition to be bacteriologically examined.
The Samples of surfaces were classified and listed in Table 1. Swab samples were stored and transported inside an ice box. The samples collected along the preparation were examined 5 times also as swabs whereas steam pots were estimated in 12 replicates.

\section{Preparation and dilution of samples}

The ten grams of every sample was aseptically weighed during a sterile Petri dish, diluted with 90 $\mathrm{ml}$ saline, and homogenized using a stomacher for two minutes. A Serial dilution in saline was prepared for every sample (ICMSF, 1986).

\section{Swabs preparation}

Type of Samples from Handlers swabs, Surfaces swabs, Utensils' swabs and equipment swabs were swabbed by an undefined limit of approximately $100 \mathrm{~cm}^{2}$ with moistened medical gauze (Bryant et al 2003).

The prepared samples were subjected to examinations cleared in Table 2.

\section{Method}

\section{Food preparation and distribution}

The product consisted of frozen chicken only no abnormal appearance Storage $\leq-18^{\circ} \mathrm{C}$ which after being boiled, dressed in stewed tomato juice, roasted inside the oven, and finally cut into four potions during the serving step (Fig. 1).

\section{Process flow chart}

Raw materials, processing and packaging steps were described in Fig. 1, where data needed for microbiological hazard analyses, applied time and temperature throughout the process and distribution are explained (ILSI, 2004).

\section{Hazard analysis}

An analysis of hazard was implemented in Cairo University dormitory restaurant (the female student departments) which is classified as industrial catering and cook/hot holds systems. During hazard analysis all procedures concerned with production, distribution and use of materials for potential problems that could occur were evaluated. 
Table 1. Samples collected from different sources during 2017 and 2019

\begin{tabular}{|l|c|c|}
\hline \multicolumn{1}{|c|}{ Type of samples } & $\begin{array}{c}\text { Number of } \\
\text { processing } \\
\text { steps }\end{array}$ & $\begin{array}{c}\text { Number of } \\
\text { samples * }\end{array}$ \\
\hline Chicken & 8 & 240 \\
Handlers swabs & - & 90 \\
Surfaces swabs & - & 120 \\
Instruments, and equipment, swabs (steam pots, mincer, and tin opener) & - & 90 \\
Utensils, swabs (roasting trays, pots, mobile tanks, trolley tanks, colanders, \\
and skimmers)
\end{tabular}

* Some samples before HACCP application = number of samples after HACCP application.

Table 2. Media and incubation conditions applied in microbiological analysis.

\begin{tabular}{|c|c|c|c|c|c|}
\hline \multirow{2}{*}{$\begin{array}{l}\text { Microbiological } \\
\text { determination }\end{array}$} & \multirow[t]{2}{*}{ Methods } & \multirow[t]{2}{*}{ Medium used } & \multicolumn{2}{|c|}{ Incubation conditions } & \multirow[t]{2}{*}{ References } \\
\hline & & & $\begin{array}{c}\text { Temperature } \\
\left({ }^{\circ} \mathrm{C}\right)\end{array}$ & $\begin{array}{l}\text { Period } \\
\text { (hours) }\end{array}$ & \\
\hline $\begin{array}{c}\text { Total viable } \\
\text { bacteria count }\end{array}$ & $\begin{array}{l}\text { Pour plate } \\
\text { count }\end{array}$ & Nutrient agar medium & $37^{\circ} \mathrm{C}$ & $24-48$ & ICMSF, 1978 \\
\hline $\begin{array}{l}\text { Spore- former } \\
\text { count }\end{array}$ & $\begin{array}{l}\text { Pour plate } \\
\text { count }\end{array}$ & Nutrient agar medium & $35^{\circ} \mathrm{C}$ & $24-48$ & Sneath, 1986 \\
\hline $\begin{array}{l}\text { Bacillus cereus } \\
\text { count }\end{array}$ & $\begin{array}{l}\text { Pour plate } \\
\text { count }\end{array}$ & $\begin{array}{c}\text { Polymyxin Pyruvate } \\
\text { Egg-yolk Mannitol } \\
\text { Bromothymol Blue } \\
\text { agar }\end{array}$ & $30^{\circ} \mathrm{C}$ & $24-48$ & Harrigan, 1998 \\
\hline $\begin{array}{c}\text { Staphylococcus } \\
\text { aureus }\end{array}$ & $\begin{array}{l}\text { Pour plate } \\
\text { count }\end{array}$ & Baird-Parkers medium & $37 \circ \mathrm{C}$ & 24 & Harrigan, 1998 \\
\hline Coliforms count & $\begin{array}{l}\text { Most Proba- } \\
\text { ble count }\end{array}$ & $\begin{array}{l}\text { MacConkeys broth } \\
\text { medium }\end{array}$ & $37^{\circ} \mathrm{C}$ & 48 & ICMSF, 1978 \\
\hline Faecal Coliforms & $\begin{array}{c}\text { Most } \\
\text { Probable } \\
\text { count }\end{array}$ & $\begin{array}{c}\text { Brilliant Green } \\
\text { Lactose Bile Broth }\end{array}$ & $44.5^{\circ} \mathrm{C}$ & $24-48$ & ICMSF, 1978 \\
\hline $\begin{array}{c}\text { Total Molds and } \\
\text { Yeasts }\end{array}$ & $\begin{array}{l}\text { Pour plate } \\
\text { count }\end{array}$ & $\begin{array}{l}\text { Sabouraud Dextrose } \\
\text { Agar }\end{array}$ & $20-25^{\circ} \mathrm{C}$ & $72-120$ & Bridson, 1998 \\
\hline $\begin{array}{c}\text { Detection of } \\
\text { Salmonella spp. }\end{array}$ & $\begin{array}{l}\text { Most } \\
\text { Probable } \\
\text { count }\end{array}$ & $\begin{array}{c}\text { Bismuth Sulphite } \\
\text { Agar }\end{array}$ & $37^{\circ} \mathrm{C}$ & $24-48$ & ICMSF, 1978 \\
\hline $\begin{array}{l}\text { Detection of } \\
\text { Shigella spp. }\end{array}$ & Pour plate & $\begin{array}{c}\text { Salmonella-Shigella } \\
\text { Agar }\end{array}$ & $37^{\circ} \mathrm{C}$ & 14 & ICMSF, 1978 \\
\hline $\begin{array}{c}\text { Detection of } \\
\text { Listeria } \\
\text { monocytogenes }\end{array}$ & Pour plate & $\begin{array}{c}\text { Listeria Selective } \\
\text { medium }\end{array}$ & $35^{\circ} \mathrm{C}$ & $18-24$ & Bridson, 1998 \\
\hline $\begin{array}{l}\text { Clostridium } \\
\text { perfringens }\end{array}$ & Pour plate & Perfrifngens agar & $35^{\circ} \mathrm{C}$ & $18-24$ & Bridson, 1998 \\
\hline
\end{tabular}




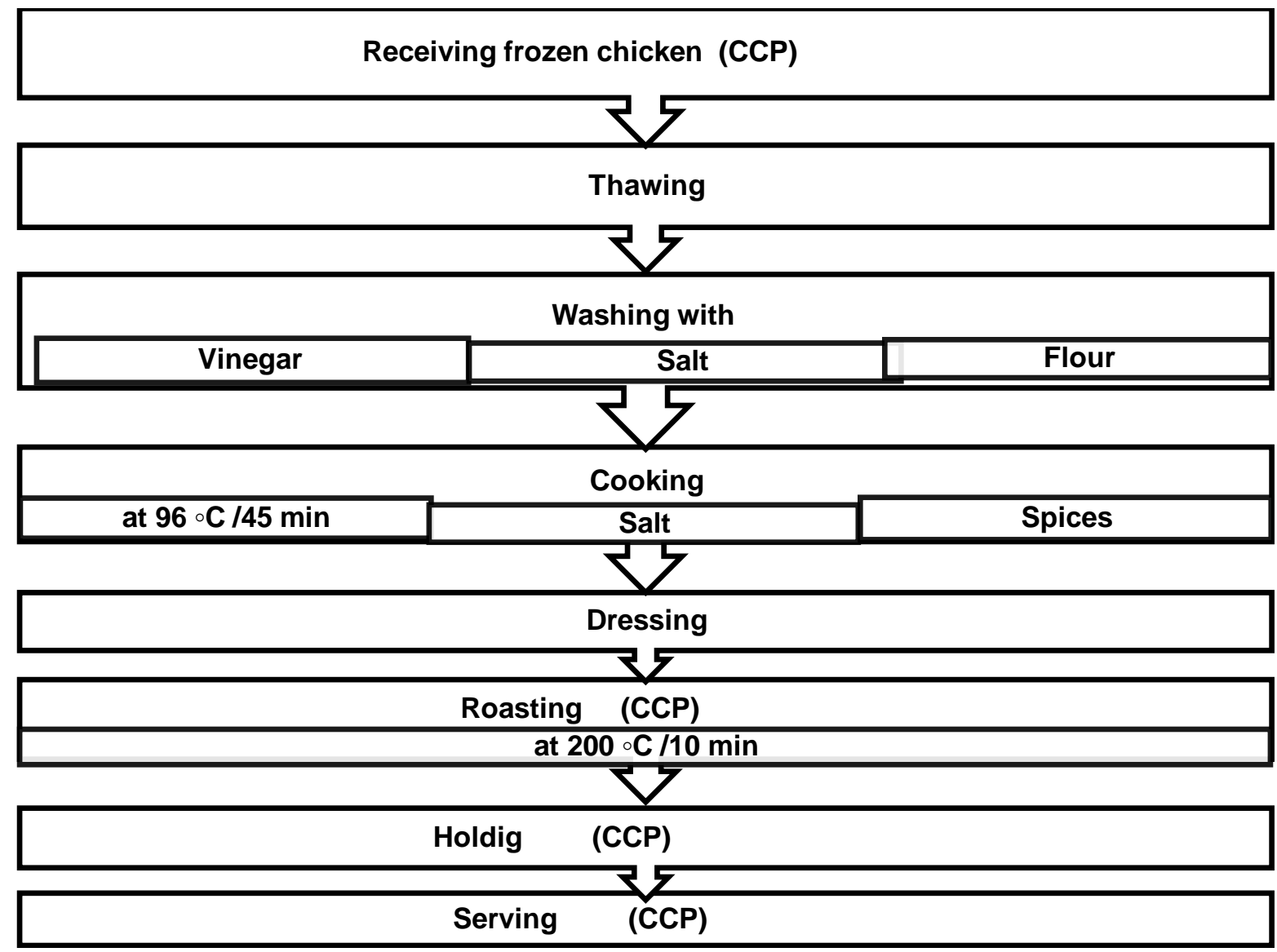

Fig. 1. Flow diagram of a roasted chicken meal process steps

The (CCPs) were studied throughout the entire production chain started with the receiving of the raw chicken and ended with serving the final roasted chicken meals.

The processing of roasted chicken was included in the application of the HACCP system. ILSI (2004).

$$
P=\frac{B-A}{A} * 100
$$

\section{Monitoring procedures establishment}

All CCPs in process were monitored to ensure that process remains with the critical limits and the method for determining the frequency of CCPs evaluation was established as well. Microbiological measurements and observation of a CCP related to its critical limits were nominated for product and CCP.

\section{Reduction percentages}

To calculate percentage decrease of the mean value of Total viable bacteria, Molds \& yeasts, Coliforms, and Spore-forms of roasted chicken meal vs. the application of HACCP throughout the production process percentage reduction formula reported by (Benham et al 2011) was used.

Where: $\mathrm{P}$ is the percentage of reduction, $B$ is the number of viable microorganisms before treatment, $A$ is the number of viable microorganisms after treatment.

\section{Statistical analysis}

All statistical analyses of the microbiological results were performed using the SPSS (V. 21) program upon completion of data collection. Data were 
revised and each sheet was coded and scored manually, after that, it was analyzed and tabulated using the Statistical Package for the Social Sciences (SPSS) version 21 (IBM Corp Relensed, 2012).

\section{RESULT AND DISCUSSION}

\section{Food analyses}

The obtained results in Table 3, showed that the highest mean value of TVB, yeast and mold, sporeformer and coliform (cfu/g) of examined chicken samples from receiving to serving were $1.12 \times 10^{5}$, $7.4 \times 10^{3}, 2.8 \times 10^{4}$, and $1.6 \times 10^{3}$ in washing chicken, in thawing, in washing, and washing steps respectively, and the lowest was $3.98 \times 10^{3}, 3.2 \mathrm{X}$ $10^{2}, 1.2 \times 10^{3}$, and $6.1 \times 10^{2}$ in serving, dressing, receiving, and receiving steps, respectively.

Before the implementation of the HACCP system, the microbiological profiles are illustrated in Table (3). The analyzed chicken samples showed the presence of Salmonella spp., L. monocytogenes, B. cereus, Staph. aureus, Cl. perfringens, and Shigella spp. during the assembly steps.

The data shown a wide gap between the results before and after application of HACCP in the serving step translated in a highly significant comparison between the data, where $p$ was $<0.0001$ in the examination of total viable bacteria, molds and yeasts and spore-formers counts. Kassem et al (2004), reported that the microbial count after GMP application was the lowest in $100 \%$ of investigated cooked chicken in the range $10^{2}<10^{3} \mathrm{CFU} / \mathrm{G}$. They also found that $B$. cereus was found in cooked chicken, while, Santos et al (2003), the detection of Staph. aureus, Salmonella spp., faecal coliforms, and $\mathrm{Cl}$. perferingens were negative in all samples before and after GMP application.

These trends are also in agreement with that reported by Santana et al (2009) in the adoption of GMP on meals served to children in a public school in Brazil, and found that chicken with tomato sauce contained thermo-tolerant coliforms ( $23 \mathrm{cells} / \mathrm{g}$ ) before GMP, while was not detected after implementation of GMP. They reported that Salmonella ssp. was found in chicken samples after cooling.

Recently, Osimani and Clementi (2016 a and b) concluded that the spread of foodborne disease that may leads to hospitalization and death is the main reason for the contribution of mass catering systems in Europe. Application of HACCP system help in monitoring microbiological parameters and provides a timely assessment of sanitary conditions of food-producing plants where several factors such as: food temperature holding and transportation affect the final quality produced by catering system and may lower the quality of a dish. It worth to mention that microbiological evaluation of meals at the centralized facility and of meals collected at the satellite kitchens can provide further information on possible food contamination or inappropriate maintenance during transportation or just before serving.

Fig. 2, illustrate the reduction percentage of total viable bacteria, Molds \& yeasts, Coliforms, and Spore-forms in the receiving, thawing, and wishing steps which varied between 17 and $100 \%$ while the reduction in the boiling and roasting steps is zero because these steps were from any detectable levels of microorganisms before and after HACCP application in roasted chicken. The highly significant reduction of Total viable bacteria, Molds \& yeasts, and Coliforms were recorded in the Holding step. The highest reduction percentage of the mean value of Total viable bacteria, Molds \& yeasts, Coliforms, and Spore-forms in serving step of roasted chicken meal after application of the HACCP system recorded 96 to $100 \%$.

Kassem et al (2004), reported that the microbial count after GMP application was the lowest in 100\% of investigated cooked chicken in the range $10^{2}<$ $10^{3} \mathrm{CFU} / \mathrm{G}$. They also found that B.cereus was found in cooked chicken, while, Santos et al (2003), the detection of Staph. aureus, Salmonella spp., faecal coliforms, and $\mathrm{Cl}$. perferingens were negative in all samples before and after GMP application.

\section{Microbial analysis of Swabs \\ Handlers swab analysis}

Four groups of swabs were taken before and after HACCP application it taken from handlers, surfaces, utensils (roasting trays, pots, mobile tanks, trolly tanks, colander, scoop, and skimmer) and equipment (steam pots, mincer and tin opener) before and after HACCP had been fulfilled.

None of the swab samples were found to be positive to $\mathrm{Cl}$. perfringens, Salmonella spp., and Shigella spp. within the three sorts of handlers' swab samples also as $L$. monocytogenes, faecal coliforms and E. coli in cookers' and serving chefs' swab samples, neither before nor after application of HACCP. After application of HACCP, the microbial loads, i.e. total viable bacteria, molds and yeasts, coliforms, faecal coliforms, E. coli, B. cereus, Staph. aureus, spore-formers, and L. monocytogenes, in hands, had, $100 \%$ dipped vs. before application of HACCP that's thanks to using sterile gloves (Table 4). 
Table 3. The microbiological profiles of roasted chicken meal throughout the production line before and after the HACCP application

\begin{tabular}{|c|c|c|c|c|c|}
\hline Process steps & Statistics & $\begin{array}{l}\text { TVB } \\
\times 10^{3}\end{array}$ & $\begin{array}{c}\text { Molds \& yeasts }{ }^{1} \\
\times 10^{2}\end{array}$ & $\begin{array}{c}\text { Spore-for- } \\
\text { mers } \\
\times 10^{3} \\
\end{array}$ & $\begin{array}{l}\text { Coliforms } \\
\qquad 10^{2}\end{array}$ \\
\hline $\begin{array}{l}\text { Receiving of frozen } \\
\text { chicken }\end{array}$ & $\begin{array}{l}b \\
a \\
p\end{array}$ & $\begin{array}{r}42.0 \\
12.0 \\
0.201 \\
\end{array}$ & $\begin{array}{c}17.1 \\
4.0 \\
0.014^{*}\end{array}$ & $\begin{array}{c}1.2 \\
1.0 \\
0.23 \\
\end{array}$ & $\begin{array}{c}6.1 \\
5.0 \\
0.75 \\
\end{array}$ \\
\hline Thawing & $\begin{array}{l}b \\
a \\
p\end{array}$ & $\begin{array}{c}26.0 \\
38.0 \\
0.003^{\star *}\end{array}$ & $\begin{array}{c}74.0 \\
9.0 \\
0.013^{*}\end{array}$ & $\begin{array}{c}15.2 \\
7.1 \\
0.178 \\
\end{array}$ & $\begin{array}{c}9.4 \\
6.0 \\
0.32 \\
\end{array}$ \\
\hline Washing & $\begin{array}{l}b \\
a \\
p\end{array}$ & $\begin{array}{c}112.0 \\
12.1 \\
0.013^{*}\end{array}$ & $\begin{array}{c}21.6 \\
5.6 \\
0.014^{*}\end{array}$ & $\begin{array}{c}28.0 \\
2.6 \\
0.110 \\
\end{array}$ & $\begin{array}{c}16.4 \\
<10 \\
0.001^{\star \star \star}\end{array}$ \\
\hline Boiling & $\begin{array}{l}b \\
a \\
p\end{array}$ & $\begin{array}{c}<10 \\
<10 \\
-\end{array}$ & $\begin{array}{c}<10 \\
<10 \\
- \\
\end{array}$ & $\begin{array}{c}<10 \\
<10 \\
- \\
\end{array}$ & $\begin{array}{c}<10 \\
0 \\
- \\
\end{array}$ \\
\hline Dressing & $\begin{array}{l}b \\
a \\
p\end{array}$ & $\begin{array}{c}6.62 \\
<10 \\
0.001^{* * *}\end{array}$ & $\begin{array}{c}3.2 \\
<10 \\
0.001^{* * *}\end{array}$ & $\begin{array}{c}0.34 \\
<10 \\
0.001^{* * *}\end{array}$ & $\begin{array}{c}0.14 \\
- \\
0.005^{\star *}\end{array}$ \\
\hline Roasting & $\begin{array}{l}b \\
a \\
p\end{array}$ & $\begin{array}{c}<10 \\
<10 \\
- \\
\end{array}$ & $\begin{array}{c}<10 \\
<10 \\
- \\
\end{array}$ & $\begin{array}{c}<10 \\
<10 \\
- \\
\end{array}$ & $\begin{array}{l}0 \\
0 \\
- \\
\end{array}$ \\
\hline Holding & $\begin{array}{l}b \\
a \\
p\end{array}$ & $\begin{array}{c}8.78 \\
<10 \\
0.001^{* * *}\end{array}$ & $\begin{array}{c}0.37 \\
<10 \\
0.001^{\star * *} \\
\end{array}$ & $\begin{array}{c}0.39 \\
<10 \\
0.001^{* * *}\end{array}$ & $\begin{array}{l}0 \\
0 \\
- \\
\end{array}$ \\
\hline Serving & $\begin{array}{l}b \\
a \\
p\end{array}$ & $\begin{array}{c}3.98 \\
<10 \\
0.001^{* * *}\end{array}$ & $\begin{array}{c}0.21 \\
<10 \\
0.001^{\star \star \star}\end{array}$ & $\begin{array}{c}0.33 \\
<10 \\
0.001^{\star * *}\end{array}$ & $\begin{array}{c}0.21 \\
0 \\
0.012^{*}\end{array}$ \\
\hline
\end{tabular}

$\mathrm{b}:$ Mean \pm SD before the application of HACCP

a: Mean + SD after the application of HACCP

p: Significant (2 -tailed)

TVB:total viable bacteria

I: Molds and yeasts as a group

*: Significant at $p<0.05$

**: Moderately significant at $p<0.01$

***: Highly significant at $p<0.001$-ve: Negative +ve: Positive

$-: t$ cannot be computed because the standard error of the difference is 0 


\section{Reduction percentages of the mean value of Total viabl bacteria , Molds\&yeasts,Coliforms and Spore-formers of roasted chicken}

$\because$ Receiving of frozen chicken Thawing $\approx$ Washing $\square$ Boiling $\sqsubset$ Dressing $\square$ Roasting $\square$ Holding $\sharp$ Serving

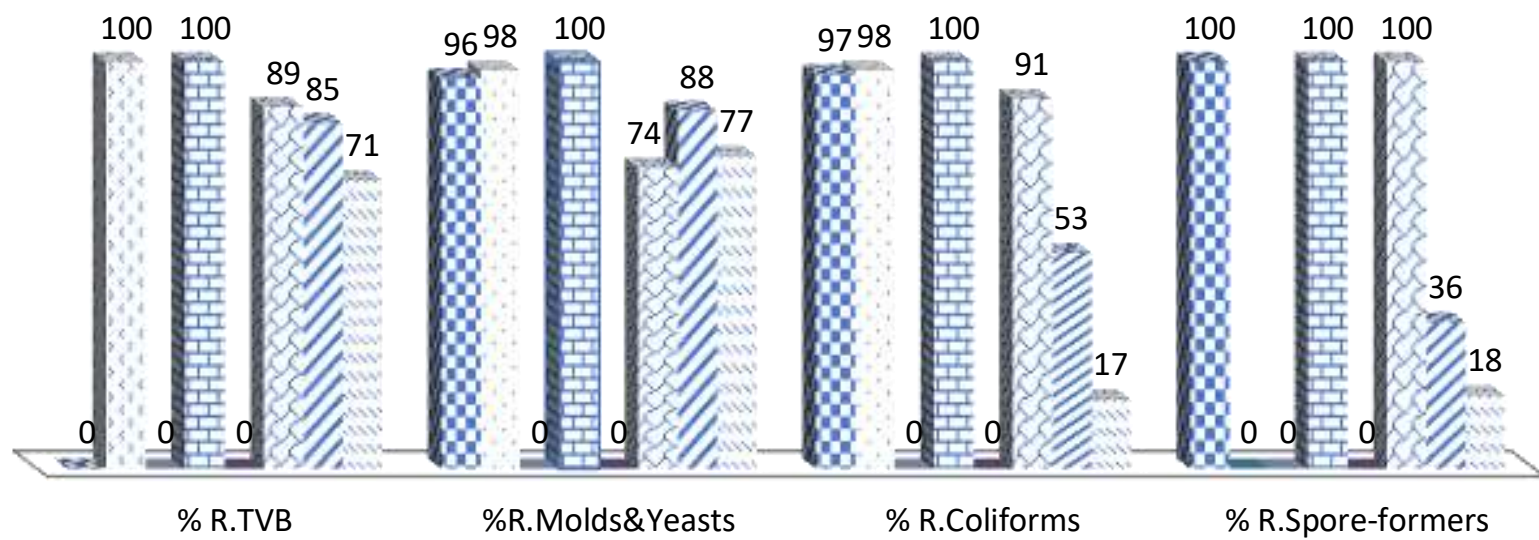

Fig. 2. Reduction percentages of the mean value of Total viable bacteria, Molds \& yeasts, Coliforms, and Spore-forms of roasted chicken meal vs. the application of HACCP throughout the production process

Table 4. The microbiological profiles and detection of handlers throughout the production line before and after the HACCP application

\begin{tabular}{|c|c|c|c|c|c|c|c|}
\hline Swabs & Statistics & $\begin{array}{l}\text { TVB } \\
\times 10^{3}\end{array}$ & $\begin{array}{c}\text { Molds \& } \\
\text { yeasts I } \\
X 10^{3} \\
\end{array}$ & $\begin{array}{l}\text { Coliforms } \\
\quad \times 10^{3}\end{array}$ & $\begin{array}{l}\text { B. cereus } \\
\times 10^{2}\end{array}$ & $\begin{array}{c}\text { Staph. } \\
\text { aureus } \\
\mathrm{X} 10^{2}\end{array}$ & $\begin{array}{c}\text { Spore } \\
\text { formers } X 10^{3}\end{array}$ \\
\hline \multirow{3}{*}{ workers } & $B$ & 63 & 5 & 0.01 & 6.2 & 4.1 & 1.4 \\
\hline & $A$ & 0.25 & 0.17 & 0 & 0 & 0 & 0.1 \\
\hline & $\mathrm{P}$ & 0.11 & 0.092 & 0.087 & 0.08 & 0.078 & 0.082 \\
\hline \multirow{3}{*}{$\begin{array}{l}\text { Cook- } \\
\text { ers }\end{array}$} & $B$ & 87 & 32 & 0.15 & 5.1 & 2.7 & 1.2 \\
\hline & $A$ & 0.22 & 0.16 & 0 & 0 & 0 & 0.09 \\
\hline & $p$ & 0.051 & 0.042 & 0.054 & 0.07 & 0.056 & 0.061 \\
\hline \multirow{3}{*}{$\begin{array}{l}\text { Serving } \\
\text { chefs }\end{array}$} & $b$ & 3.6 & 28 & 0.1 & 4.2 & 0 & 1 \\
\hline & $\mathrm{a}$ & $<10$ & 0.12 & 0 & 0 & 0 & 0.06 \\
\hline & $p$ & 0.021 & 0.016 & 0.065 & 0.084 & 0.039 & 0.072 \\
\hline
\end{tabular}

Data in Table 4 show that the highest mean value of TVB, yeast, mold and coliform (cfu/g), of examined handlers samples (workers, cookers and serving chefs) $87 \times 10^{3}, 32 \times 10^{3,} 0.15 \times 10^{3} \mathrm{cfu} / \mathrm{g}$ in cookers group .while $B$. cereus, Staph. aureus and spore-former was $6.2 \times 10^{2}, 4.1 \times 10^{3,} 1.4 \times 10^{3} \mathrm{cfu} / \mathrm{g}$ respectively. The lowest was $3.6 \times 10^{3}, 5 \times 10^{3}$ and $0.01 \times 10^{3} \mathrm{cfu} / \mathrm{g}$ in serving chefs, workers respectively. The microbial loads in hands had, 100\% dipped after HAACP application vs. before application of HACCP that is due to using sterile gloves.

In the order of practice personal hygiene, (Scmhid et al 2006) reported that due to unhygienic food handling procedures, Pathogenic microorganisms can enter food and can multiply in it due to inadequate food storage, chilling, thawing and processing parameters. 


\section{Utensils swab analysis}

Table 5 show the microbial load of utensils swabs and their reduction rate. It could be noticed that spoons had no detectable counts of any of microorganisms. While, $L$. monocytogenes, $\mathrm{Cl}$. perfringens, Salmonella spp. and Shigella spp., were not detectable in all utensils swab samples. Coliforms, B. cereus, and Staphy. aureus was not detectable only in Roasting trays swab samples.

In a comparison between the microbial results before vs. after application of HACCP. The highest result for total viable bacteria was recorded (124X $10^{3}$ vs. $\left.<10 \mathrm{CFU} / 100 \mathrm{~cm}^{2}\right)$, molds and yeasts $(52 \mathrm{X}$ $10^{3}$ vs. $<10 \mathrm{CFU} / 100 \mathrm{~cm}^{2}$ ) in scoops and coliforms $\left(0.82 \times 10^{3}\right.$ vs. $\left.<10 \mathrm{CFU} / 100 \mathrm{~cm}^{2}\right)$.

While, for $B$. cereus $\left(66 \times 10^{2}\right.$ vs. $0 \mathrm{CFU} / 100$ $\left.\mathrm{cm}^{2}\right)$ in colanders, Staph. aureus $\left(56 \times 10^{2}\right.$ vs. 0 $\left.\mathrm{CFU} / 100 \mathrm{~cm}^{2}\right)$, and spore-formers $\left(33 \times 10^{3} \mathrm{vs} .<10\right.$ $\left.\mathrm{CFU} / 100 \mathrm{~cm}^{2}\right)$ in pots. Besides, a significant reduction was detected in a population of total bacteria in scoops, roasted trays, mobile tanks, colanders, and pots swabs; for molds and yeasts in pots, colanders, scoops and skimmers swabs; for coliforms in trolly tank.

Also, the comparison between the microbial load before vs after the application of HACCP, $\mathrm{P}=$ 0 for a total viable count $\left(1.24 \times 10^{5} \mathrm{vs}<10 \mathrm{CFU} / 100\right.$ $\mathrm{cm}^{2}$ ) in Scoops swaps samples. Moreover, a significant reduction was detected in a load of TVC and molds and yeasts in Roasting trays, Pots, Trolly tanks, and Skimmers swaps samples; for coliforms in Pots, Trolly tanks and Skimmers swaps; for B. cereus and Staph. aureus in Pots, Scoops, and Skimmers swaps; and for spore former in Roasting trays, Pots, Trolly tanks, Scoops, and Skimmers.

Afifi and Kassem (2004) recorded that, after each working period all food utensils must be cleaned. Also, Tavakoli and Riazipour (2008) showed that contaminated dishes would transfer pathogenic bacteria to the cooked foods in restaurant.

\section{Equipment swab analysis}

Table 6 shows the microbial profiles of instruments or equipment used in the preparation of foods. It could be observed that the highest result for total viable bacteria, coliforms, and $B$. cereus was recorded $\left(78 \times 10^{3}\right.$ vs. $<0.06 \times 10^{3} \mathrm{CFU} / 100$ $\left.\mathrm{cm}^{2}\right),\left(1.2 \times 10^{3}\right.$ vs. $\left.0 \mathrm{CFU} / 100 \mathrm{~cm}^{2}\right)$ and $\left(8.4 \times 10^{2}\right.$ vs. $0 \mathrm{CFU} / 100 \mathrm{~cm}^{2}$ ) respectively in mincer while Staph. aureus and molds and yeasts were recorded $\left(4.1 \times 10^{2}\right.$ vs. $\left.0 \mathrm{CFU} / 100 \mathrm{~cm}^{2}\right)$ and $\left(28 \times 10^{3} \mathrm{vs}\right.$. $<0.018 \times 10^{3} \mathrm{CFU} / 100 \mathrm{~cm}^{2}$ ) respectively in steam pots.

For B. cereus $\left(66 \times 10^{2}\right.$ vs. $\left.0 \mathrm{CFU} / 100 \mathrm{~cm}^{2}\right)$ in colanders, Staph. aureus $\left(56 \times 10^{2}\right.$ vs. $0 \mathrm{CFU} / 100$ $\left.\mathrm{cm}^{2}\right)$, and spore-formers (33 X $10^{3}$ vs. $<10 \mathrm{CFU} / 100$ $\mathrm{cm}^{2}$ ) in pots. In addition, a significant reduction was detected in a population of total bacteria in scoops, roasted trays, mobile tanks, colanders, and pots swabs; for molds and yeasts in pots, colanders, scoops and skimmers swabs; for coliforms in trolly tank.

The results recorded by Kassem et al (2004) after the application of GMP, agreement with our results after the application of HACCP. Although microbial load in swabs of equipment before application of GMP was $1.5 \times 10^{4} \mathrm{CFU} 120 \mathrm{~cm}^{2}$ of the aerobic bacterial count. Detection of faecal coliforms, $B$. cereus, Salmonella spp, and $\mathrm{Cl}$. perfringens were negative; while molds and yeasts were $4.2 \times 10^{5}$ $\mathrm{CFU} / 20 \mathrm{~cm}^{2}$. All swabs were free from microorganisms after the application of GMP.

\section{Work surfaces swab analysis}

Table 7 shows that microbial load in swabs of preparation area, kitchen area, serving area, and boards shows the microbial profiles could be observed that, The highest result for total viable bacteria, molds and yeasts and $B$. cereus was recorded $\left(122 \times 10^{3}\right.$ vs. $\left.<0.19 \times 10^{3} \mathrm{CFU} / 100 \mathrm{~cm}^{2}\right),\left(34 \times 10^{3}\right.$ vs. $\left.0.2 \times 10^{3} \mathrm{CFU} / 100 \mathrm{~cm}^{2}\right)$ and $\left(7.1 \times 10^{2}\right.$ vs. 0 CFU $/ 100 \mathrm{~cm}^{2}$ ) respectively in the kitchen while coliforms were $\left(0.45 \times 10^{3}\right.$ vs. $\left.0 \mathrm{CFU} / 100 \mathrm{~cm}^{2}\right)$ in boards. For Staph. aureus was recorded $\left(4.1 \times 10^{2}\right.$ vs. $0 \mathrm{CFU} / 100 \mathrm{~cm}^{2}$ ) in the serving area.

In a study on, Ismail et al (2013) reported that the use of microbiological analyses of surfaces as one of the tools to control the hygiene of products to control of microbial hazards to prevent food safety issues. This preventive approach used now widely used in The HACCP-based processes.

For this respect, floor, wall, and work surfaces must be cleaned and sanitized at least once a day using sodium hypochlorite solution at $500 \mathrm{mg}-1$ for 30 min. (Santana et al 2009). 
Table 5. The microbiological profiles and detection of utensils throughout the production line before and after the HACCP application

\begin{tabular}{|c|c|c|c|c|c|c|c|}
\hline Swabs & Statistics & $\begin{array}{l}\text { TVB } \\
\times 10^{3}\end{array}$ & $\begin{array}{c}\text { Molds \& } \\
\text { yeastsl } \\
\mathrm{X} 10^{3} \\
\end{array}$ & $\begin{array}{l}\text { Coliforms } \\
\times 10^{3}\end{array}$ & $\begin{array}{c}\text { B.cereus } \\
\times 10^{2} \\
\end{array}$ & $\begin{array}{c}\text { Staph.aureus } \\
\times 10^{2}\end{array}$ & $\begin{array}{c}\text { Sporeformers } \\
\times 10^{3}\end{array}$ \\
\hline \multirow{3}{*}{$\begin{array}{l}\text { Roasting } \\
\text { trays }\end{array}$} & $b$ & 3.8 & 3.2 & 0 & 0 & 0 & 12 \\
\hline & a & $<10$ & $<10$ & 0 & 0 & 0 & $<10$ \\
\hline & $p$ & 0.022 & 0.026 & 0 & - & - & 0.016 \\
\hline \multirow{3}{*}{ Pots } & $b$ & 60 & 42 & 0.8 & 34 & 44 & 33 \\
\hline & a & $<10$ & $<10$ & 0 & 0 & 0 & $<10$ \\
\hline & $p$ & 0.014 & 0.02 & 0.062 & 0.028 & 0.041 & 0.027 \\
\hline \multirow{3}{*}{ Trolly tanks } & $b$ & 44 & 22 & 0.82 & 48 & 29 & 28 \\
\hline & a & $<10$ & $<10$ & 0 & 0 & 0 & $<10$ \\
\hline & $p$ & 0.094 & 0.08 & $0 . .031$ & 0.13 & 0.1 & 0.096 \\
\hline \multirow{3}{*}{ Colanders } & $b$ & 62 & 42 & 0.51 & 66 & 42 & 32 \\
\hline & a & $<10$ & $<10$ & 0 & 0 & 0 & $<10$ \\
\hline & $p$ & 0.21 & 0.14 & 0.013 & 0.32 & 0.27 & 0.11 \\
\hline \multirow{3}{*}{ Scoops } & $b$ & 124 & 52 & 0.16 & 28 & 28 & 5.2 \\
\hline & a & $<10$ & $<10$ & 0 & 0 & 0 & $<10$ \\
\hline & $p$ & 0.621 & 0.59 & 0.1 & 0.04 & 0.03 & 0.031 \\
\hline \multirow{3}{*}{ Skimmers } & $b$ & 6.2 & 1.4 & 0.11 & 19 & 56 & 4.1 \\
\hline & a & $<10$ & $<10$ & 0 & 0 & 0 & $<10$ \\
\hline & $p$ & 0.022 & 0.011 & 0.01 & 0.042 & 0.084 & 0.024 \\
\hline
\end{tabular}

Table 6. The microbiological profiles and detection of instruments and equipment throughout the production line before and after the HACCP application

\begin{tabular}{|c|c|c|c|c|c|c|c|}
\hline Swabs & Statistics & $\begin{array}{l}\text { TVB } \\
\times 10^{3}\end{array}$ & $\begin{array}{c}\text { Molds \& } \\
\text { yeastsl } \\
\mathrm{X} 10^{3} \\
\end{array}$ & $\begin{array}{c}\text { Coliforms X } \\
10^{3}\end{array}$ & $\begin{array}{c}\text { B.cereus } \\
\times 10^{2}\end{array}$ & $\begin{array}{c}\text { Staph.aureus } \\
\qquad 10^{2}\end{array}$ & $\begin{array}{c}\text { Sporeformers } \\
\times 10^{3}\end{array}$ \\
\hline \multirow{3}{*}{ Steam pots } & $b$ & 32 & 28 & 0.001 & 6.1 & 4.1 & 1.3 \\
\hline & $a$ & 0.3 & 0.18 & 0 & 0 & 0 & 0.11 \\
\hline & $p$ & 0.082 & 0.14 & 0.01 & 0.42 & 0.34 & 0.21 \\
\hline \multirow{3}{*}{ Mincer } & b & 78 & 0.54 & 1.2 & 8.4 & 1.4 & 1.2 \\
\hline & a & 0.06 & $<10$ & 0 & 0 & 0 & 0.2 \\
\hline & $\mathrm{p}$ & 0.084 & 0.021 & 0.04 & 0.084 & 0.071 & 0.061 \\
\hline \multirow{3}{*}{ Tin opner } & $b$ & 9.1 & 4.2 & 0 & 0 & 0 & 0.3 \\
\hline & a & $<10$ & $<10$ & 0 & 0 & 0 & $<10$ \\
\hline & $p$ & 0.072 & 0.048 & 0 & 0 & 0 & 0.018 \\
\hline
\end{tabular}


Table 7. The microbiological profiles and detection of work surfaces throughout the production line before and the after the HACCP application

\begin{tabular}{|l|c|c|c|c|c|c|c|}
\hline Swabs & Statistics & $\begin{array}{c}\text { TVB } \\
\mathbf{X 1 0 ^ { 3 }}\end{array}$ & $\begin{array}{c}\text { Molds \& } \\
\text { yeasts } \\
\mathbf{X 1 0 ^ { 3 }}\end{array}$ & $\begin{array}{c}\text { Coliforms } \\
\mathbf{X ~ 1 0 ^ { 3 }}\end{array}$ & $\begin{array}{c}\text { B.cereus } \\
\mathbf{X 1 0 ^ { 2 }}\end{array}$ & $\begin{array}{c}\text { Staph.aureus } \\
\mathbf{X 1 0 ^ { 2 }}\end{array}$ & $\begin{array}{c}\text { Sporeformers } \\
\mathbf{X 1 0 ^ { 3 }}\end{array}$ \\
\hline \multirow{3}{*}{ Preparation } & $\mathrm{b}$ & 74 & 4.6 & 0.03 & 6.2 & 3 & 1.6 \\
& $\mathrm{a}$ & 22 & 0.14 & 0 & 0 & 0 & 0.12 \\
& $\mathrm{p}$ & 0.01 & 0.07 & 0.01 & 0.091 & 0.051 & 0.052 \\
\hline \multirow{3}{*}{ Kitchen } & $\mathrm{b}$ & 122 & 34 & 0.22 & 7.1 & 4 & 1.3 \\
& $\mathrm{a}$ & 0.019 & 0.2 & 0 & 0 & 0 & 0.17 \\
& $\mathrm{p}$ & 0.02 & 0.04 & 0.06 & 0.01 & 0.012 & 0.061 \\
\hline \multirow{3}{*}{ Serving area } & $\mathrm{b}$ & 32 & 28 & 0.001 & 6.1 & 4.1 & 1.3 \\
& $\mathrm{a}$ & 0.3 & 0.18 & 0 & 0 & 0 & 0.11 \\
& $\mathrm{p}$ & 0.082 & 0.14 & 0.01 & 0.42 & 0.42 & 0.21 \\
\hline & $\mathrm{b}$ & 0.27 & 17 & 0.45 & 1.7 & 0 & 0.81 \\
& $\mathrm{a}$ & $<10$ & $<10$ & 0 & 0 & 0 & $<10$ \\
\hline
\end{tabular}

\section{CONCLUSION}

The principles of HACCP should be applied to commercial and domestic catering and food preparation of a wide variety of raw materials processes and combinations of ingredients used. Qualitative risk assessments are also often done for the prevention of food poisoning in both domestic and commercial settings.

\section{REFERENCES}

Afifi A.H.E. and Kassem M.M. (2004). Microbiological studies on some foods which served at the teaching hospitals in Cairo and Giza governerates. Bull. Nat. Nutr. Inst. Cairo, Egypt, 24, 1940.

Benham B., Krometis L.A., Yagow G., Kline K. and Dillaha T. (2011). Applications of microbial source tracking in the TMDL process. In Microbial Source Tracking: Methods, Applications, and Case Studies. Springer, USA, NY. pp. 313335.

Bridson E.Y. (1998). The Oxoid Manual. $8^{\text {th }}$ ed., Oxoid Ltd., Wade Road, Basingstoke, Hampshire, RG248 PW, London, U.K., 371 p.
Bryant J., Brereton D.A. and Gill C.O. (2003). Implementation of a validated HACCP system for the control of microbiological contamination of pig carcasses at a small abattoir. Can. Vet. J., 44, 51-55.

CDC (2015). Estimates of foodborne illness in the United States. Available at: http://www.cdc.gov/foodborneburden/20 15foodborne-estimates.html\#annual

Akabanda F., Hlortsi E.H. and Owusu-Kwarteng J. (2017). Food Safety Knowledge, Attitudes, and Practices of Institutional Food-Handlers in Ghana. BMC Public Health, 17, 40. https://doi.org/10.1186/s12889-016-3986-9

Davis S.G. (2018). Microbial safety of foods in selected senior high schools. MSc. Thesis, Dept. of Food Science and Technology, Fac. of Biosciences, Kwame Nkrumah Univ., of Sci. and Technology, Kumasi, Ghana. 2, 6-11.

Harrigan W.F. (1998). Laboratory Methods in Food Microbiology $3^{\text {rd }}$ ed. Academic Press Ltd., 532 p.

IBM Corp Released (2012). IBM SPSS Statistics for Windows, Version 21.0. Armonk, NY: IBM Corp.

ICMSF (1978). Microorganisms in Food 1. Their significance and Methods of Enumeration ( $2^{\text {nd }} \mathrm{ed}$ ), Toronto, University of Toronto Press, 434 p. 
quality of roasted chicken meals

ICMSF (1986). Microorganisms in Foods 2. Sampling for microbiological analysis: Principles and specific applications. (2 ${ }^{\text {nd }}$ ed.), University of Toronto Press, $278 \mathrm{p}$.

ILSI (2004). A simple guide to understanding and applying the Hazard. Analysis Critical Control Point. ILSI Europe Risk Analysis in Microbiology Task Force, $23 \mathrm{p}$.

Ismaïl R., Aviat F., Michel V., Le Bayon I., GayPerret P., Kutnik M. and Fédérighi M. (2013). Methods for recovering microorganisms from solid surfaces used in the food industry: a review of the literature. Int. J. of Environmental Research and Public Health, 10, 6169-6183.

Kassem M.M., El-Syaed A.H., Afifi E.A. and Abo Elmakarem W. (2004). Effect of good manufacturing practices "GMP" on food safety. Bull. Nat. Nutr. Inst. of the Arab Republic of Egypt, 3, 210-227.

Osimani A. and Clementi F. (2016a). The catering industry as a source of campylobacteriosis in Europe- A review. Int. J. Hosp. Manag. 54, 6874.

Osimani A. and Clementi F. (2016b). The occurrence of Listeria monocytogenes in mass catering: an overview in the European Union. Int. J. Hosp. Manag. 57, 9-17.

Santana N.G., Almeida R.C.C., Ferreira J.S. and Almeida P.F. (2009). Microbiological quality and safety of meals served to children and the adoption of good manufacturing practices in public school catering in brazil. Food Con., 20, 255-261.

Santos L.R. dos; Nascimento V.P. do; Oliveria S.D. de; Rodrigues D.P., Reis E.M.F. dos; Seki L.M., Riberiso A.R., Fernandes S.A., dos Santos L.R., do-Nascimento V.P., de-Oliveria S.D. and dos-Reis E.M.F. (2003). Phage types of Salmonella enteritids isolated from clinical and food samples, and from broiler carcasses in Southern Brazil. Revista do Instituto de Medicina Tropical de Sao Paulo, 45, 1-4.

Schmid D., Stüger H.P., Lederer I., Pichler A.M., Kainz-Arnfelser G., Schreier E. and Allerberger F. (2006). A foodborne norovirus outbreak due to manually prepared salad, Austria 2006. Infection, 35, 232-239.

Sneath P.H.A. (1986). Endospore-forming grampositive rods and cocci. In: "Bergy's Manual of Systematic Bacteriology" (Sneath, P.H.A.; Mair N.S.; Sharpe M.E. and Holt J.C.), Williams and Wilkins, Baltimore, Md., 2, 1104-1207.

Tavakoli H.R. and Riazipour M. (2008). Microbial quality of cooked meat foods in Tehran University's restaurants. Pak. J. Med. Sci., 24, 595599.

WHO (1999). Strategies for Implementing HACCP in Small and/or Less Developed Business, WHO Consultation. The Hague, the Netherlands, pp. 16-19. 


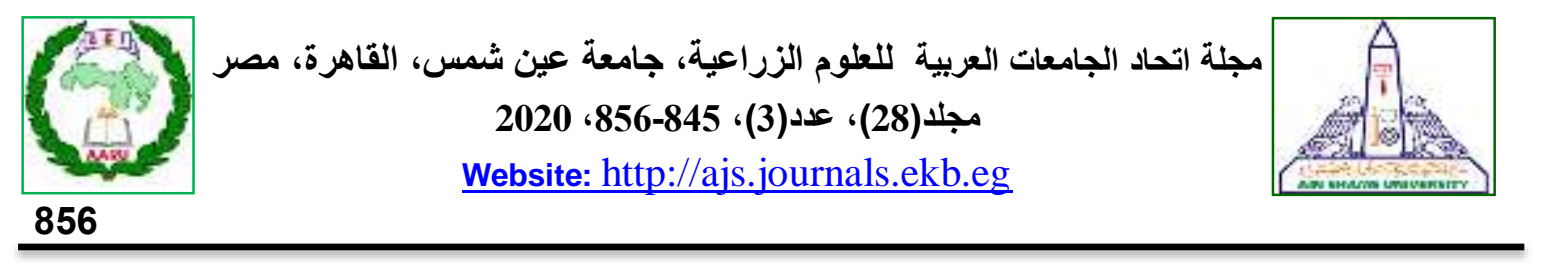

\section{تطبيق نظام تحليل المخاطر ونقاط التحكم الحرجة في نظام التموين والجودة الميكروبيولوجية لوجبات الاجاج المشوي}

[61]

$$
\begin{aligned}
& \text { حسين ربيع على1" - يسرى أحمد عبد الدايم' - يحيى على الاين حماد } 1 \text { ـ } \\
& \text { محمد زكريا صادق } 2 \\
& \text { 1- قسم علوم الأغذية - كلية الزراعة - جامعة عين شمس - ص.ب } 68 \text { - حدائق شبرا } 11241 \text { - القاهرة - مصر }
\end{aligned}
$$

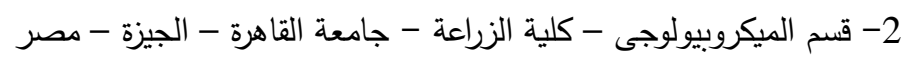

*Corresponding author: hussien elswify@hotmail.com

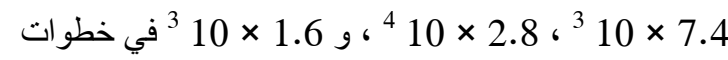

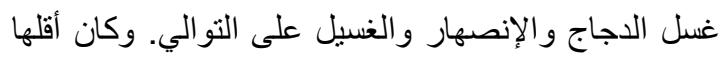
×6.1 $و^{3} 10 \times 1.2 و^{2} 10 \times 3.2 و^{3} 10 \times 3.98$ 10 20 في خطو × 108

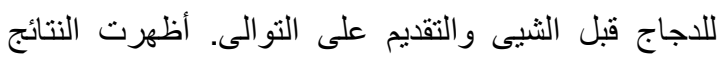

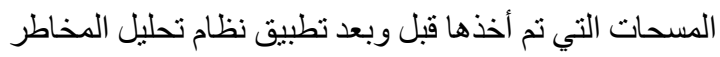

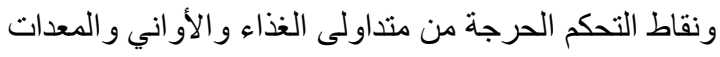

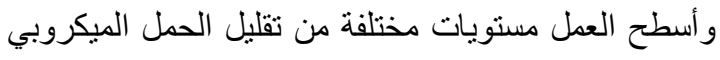

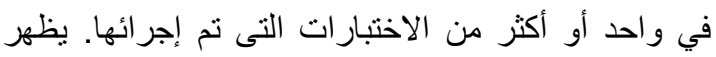

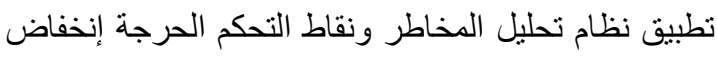

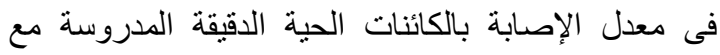

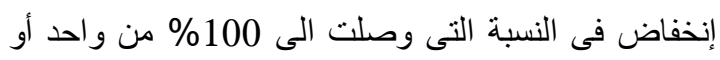
أكثر من المجمو عات الميكروبية فى خطوة التقديم إحصائياً

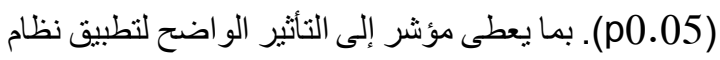
الهاسب (HACCP). بمكن أيضا إستخدام نظام تحليل

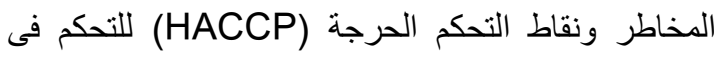

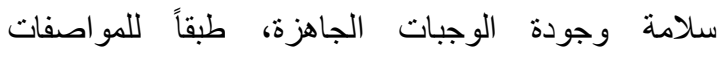

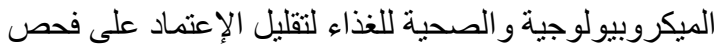

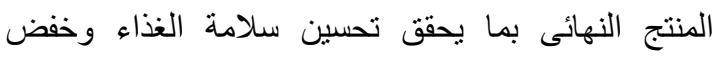
التكاليف المرتبطة بمخاطر الغذاء.

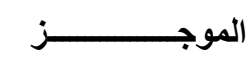

تهدف الدراسة إلى تقييم الجودة الميكروبيولجية لوجبات الدجاج المشوى (ن=240) ومسحات من أسطح العمل

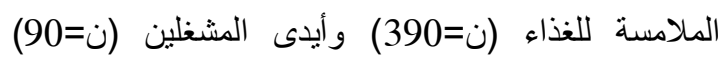

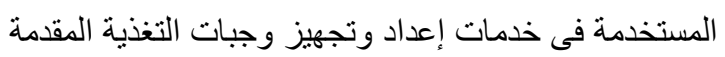

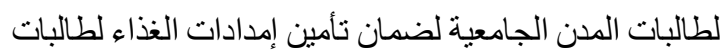

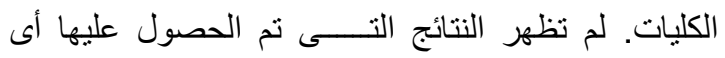

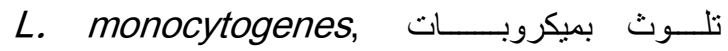
Salmonella spp., Shigella spp., and Clostridium perfringens فى حين ان التذبذب فى الحمل الميكروبى أو أعــــاد البكتريا

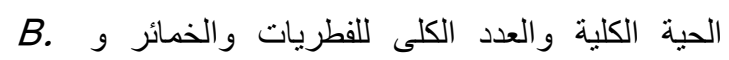
cereus, Staph. aureus, spore-formers, coliforms فى الوجبات المقدمة بسبب عدم كفاية إجر اءات المناولة أو المعالجة وتكاثر الكائنات الحية الدقيقة أثناء

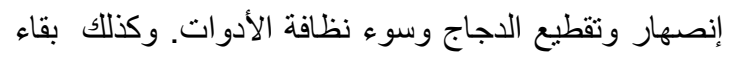
الكائنات الحية الدقيقة أثناء عملية الطهى. كانت عينات الدجاج تحت الإختبار من مرحلة الاستلام حتى مرحلة التقديم مسجلة

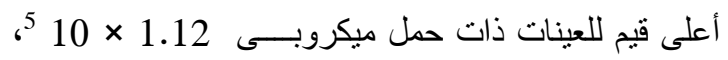

